\title{
Erythrocyte Sedimentation Rate and Total Serum Protein as Biochemical Markers of Anxiety in Chronic Obstructive Pulmonary Disease
}

\author{
ADINA MAGDALENA TURCANU ${ }^{1,2}$, DIANA VERONICA TURCU ${ }^{1}$, IRINA DOBRIN ${ }^{1 *}$, ANA CATERINA CRISTOFOR ${ }^{1 *}$, \\ VLADIMIR POROCH ${ }^{1,3 *}$, ARMAND IUSTINIAN ENACHE ${ }^{1}$ \\ ${ }^{1}$ Grigore T. Popa University of Medicine and Pharmacy, Faculty of Medicine, 16 Universitatii Str., 700115, Iasi, Romania \\ ${ }^{2}$ Clinical Hospital of Pneumology, 30 Doctor Iosif Cihac Str., 700115, Iasi, Romania \\ ${ }^{3}$ Regional Institute of Oncology, 2-4 G-ral Berthelot Str., 700483, Iasi, Romania
}

\begin{abstract}
Chronic obstructive pulmonary disease (COPD) is a medical condition which is primarily characterized by airway inflammation and destruction of the pulmonary parenchyma. Besides the well-known physical comorbidities, psychological comorbidities such as anxiety have been found to be also increased in this category of patients. Our main three hypotheses referred to the biochemical markers of COPD (erythrocyte sedimentation rate- ESR, total serum protein and forced expiratory volume in the first second- FEV1) and their power of predicting the level of anxiety in this population. The study was conducted on 150 patients suffering from COPD. Based on their anxiety level, they were distributed in 2 groups: high anxiety and low anxiety. The results showed statistical significant differences between the two experimental groups regarding all three of our dependent variables, validating all of our three hypotheses. More specific, the patients in the high anxiety group had a significantly lower mean of FEV1 compared to low anxiety group ( $M=46.01 \mathrm{vs}$. $M$ $=41.47 ; p=0.042$ ). Also, patients from the high anxiety group had a significantly higher mean of total serum proteins compared to low anxiety group $(M=9.2 \mathrm{vs} . M=8.6 ; p=0.002)$. And lastly, patients with high anxiety symptoms had a higher mean of ESR compared to those with low anxiety symptoms $(M=$ 27.54 vs. $M=22.8 ; p=0.045$ ). Therefore, these biochemical markers commonly used in the diagnosing of COPD may be also used in predicting the severity of anxiety symptoms in this at risk group of patients.
\end{abstract}

Keywords: erythrocyte sedimentation rate (ESR), chronic obstructive pulmonary disease (COPD), forced expiratory volume in the first second (FEV1), total serum protein

Chronic obstructive pulmonary disease (COPD) is a medical condition which is primarily characterized by airway inflammation and destruction of the pulmonary parenchyma. The clinical symptoms of COPD are airflow limitation and dyspnea commonly known as shortness of breath [1].

Even if the direct costs of the disease come primarily from physical rather than psychologic morbidity, the presence of psychiatric comorbidities, such as depression and/or anxiety, in patients with COPD has been showed to increase mortality and decrease functional status [2]. Furthermore, it has been shown that patients who suffer from COPD have a low level of quality of life, and this poor quality of life might be explained by high levels of anxiety and depression [3]. In addition, high depression and anxiety levels have been related to poor health outcomes in COPD patients. Moreover, some authors have suggested that depressed and anxious mood increases with the disease severity and with functional disability [4].

The prevalence of depression and anxiety in patients who suffer from COPD vary considerably across the available data from the literature. One possible explanation may lay in the variety of scales and methods used to measure such symptoms in this population. The exact causes of the observed high levels of anxiety and depression in patients who suffer from COPD have not been thoroughly explained, butseveral variables have been proposed to be implicated. These variables include longterm oxygen therapy, a percentage of predicted FEV1 (forced respiratory volume in the first second) higher than $50 \%$, living alone, sexual gender (women present a higher level of anxiety and/ or depression compared to men) and current smoking status [5-8].

In our study we used total serum protein and erythrocyte sedimentation rate (ESR) as inflammation markers. We hypothesized that these two biochemical markers of inflammation will correlate with the FEV1 level (an expected correlation), but more importantly, ESR and total serum protein will correlate with the anxiety level of our patients. Measuring the total serum protein as a marker of systemic inflammation is a popular method either in the general population or in selected categories of patients, such as those with coronary artery disease, congestive heart failure or different rheumatic disorders $[9,12]$. But most important it has also been proven to be high in individuals who suffer from COPD. In addition, it has been showed that as the level of total serum proteins increases, the level FEV1 decreases [13]. Furthermore, even in healthy individuals, total serum protein level it has been demonstrated to be inversely associated with FEV1, even after correcting for potential confounders. These results may suggest that clinically silent systemic inflammation accelerates respiratory function decline [12]. Studying the connection of total serum proteins and other COPD variables may have a huge clinical and epidemiological importance for the reason that it has been reported that the level of total serum proteins may predict mortality and cardiovascular diseases in stable COPD patients $[15,16]$. In addition, another study we found showed that increased serum proteins levels during acute periods of COPD are associated with an up-regulation of vascular endothelial growth factor, which in the end leads to further increase risk of cardiovascular complications [17, 18].

*email: irina.dobrin@umfiasi.ro; caterina.cristofor@umfiasi.ro; vladimir.poroch@umfiasi.ro 
However, a possible disadvantage of using total serum proteins as a biochemical marker of inflammation is that comorbidity frequentlyaccounts for the observed increased level, making thus difficult to isolate total serum proteins as a biochemical marker of COPD-related systemic inflammation [19-20].

On the other hand, the erythrocyte sedimentation rate (ESR) is commonly considered a non-specific index of disease activity proved useful in the follow up of patients with COPD [21, 22]. In addition, it has been found an increase level of ESR in response to rising serum levels of acute phase proteins, fibrinogen and immunoglobulins, as well as in response to anemia [23]. Therefore, one may argue that the variance from the total serum protein level may not be a pure indirect inflammatory index. However, some authors suggest that this might be an advantage rather than a limitation in the assessment of COPD patients because COPD, mainly if severe, is frequently associated with hyperfibrinogenemia and anemia [24]. Accordingly, ESR is now considered a worthy way to diagnose the potential index of COPD severity, given that, recently COPD has become a systemic more than a merely respiratory condition. Another important advantage of ESR is that this very easy, well standardized and reproducible procedure of measurement is an almost costless procedure, well suited then for undeveloped areas, where COPD prevalence is found to alarmingly increase $[25,26]$.

Therefore, that is the reason why the erythrocyte sedimentation rate (ESR) is one of the most common measures used for screening in search of inflammation in clinical medicine. An observed increase in ESR is diagnosed to signify some ongoing pathological process in the body, but one disadvantage is that it does not reveal any specific information about the nature of the possible inflammation. The general theory on why ESR level rises with inflammation in human organism is that it involves several rather diverse mechanisms. These biochemical mechanisms are a decrease concentration in hemoglobin and an increase in serum concentrations of various elongated proteins. Furthermore, another biochemical marker that might be associated with an increase in ESR may be hyperlipidemia (an abnormal elevated level of any or all lipids or lipoproteins in the blood) correlated with an elevated level of serum cholesterol. However, an increased level of ESR might also be correlated stressful situations. In addition, ESR might be influenced by an increased hemoglobin concentration, butalso as a response to certain anti-inflammatory agents such as corticosteroids [27-30]. The ESR connection with stress comes with great importance for the present research. The reason for this is that stress and anxiety are often used interchangeably, and there is overlap between them. Stress is related to the same 'fight, flight, or freeze' response as anxiety, and the physical sensations of anxiety and stress may be very similar. Furthermore, it is well known that stress is generally accompanied by sympathotonic reactions and by an increase in lipolysis and that might be the explanation for the observed increase in ESR. If this hypothesis is true than ESR rises should occur in response not only to physical stressors such as infections and inflammation but also to stimuli of a more psychological nature such as a high level of anxiety [31]. Therefore, an increased level of ESR in a patient could be associated not only with physical inflammation but also various environmental influences, including psychological factors such as anxiety disorders.

Therefore, we had three specific hypotheses when we designed our experiment. The first hypothesis refers to the connection between FEV1 and anxiety levels. Specifically we hypothesized that patients with a higher level of anxiety will present a lower level of FEV1. The second hypothesis was about how a biochemical marker of inflammation such as total serum proteins level might by associated with a high or a low level of anxiety. More specific we hypothesized that it will be a significant difference between patients with a high level of anxiety and patients with a low level of anxiety regarding total serum protein level, in the sense that patients with a high level of anxiety will also present a high level of total serum protein and patients with low anxiety will present low levels of total serum proteins. Lastly, our third hypothesis referred to the second biochemical marker of inflammation, ESR, and its connection with anxiety levels. Similar to our second premise, we hypothesized that a high level of ESR will be accompanied by a high level of anxiety, and that a low level of ESR will be accompanied by a low level of anxiety in our sample of patients.

\section{Experimental part Methods}

Our study was conducted on 150 patients, all Romanians, who were hospitalized at Sf. Spiridon Clinical Emergency Hospital in lasi (Romania). All 150 patients suffered from chronic obstructive pulmonary disease (COPD). These patients were divided in two groups according to their anxiety levels: high anxiety group and low anxiety group. The two groups were compared using statistical analysis for significant differences regarding the three dependent variables: FEV1, total serum protein and ESR. The study was conducted in accordance to the rules of the Helsinki Declaration and to some reported models [32-34].

\section{Spirometry}

The pulmonary function tests were performed using a spirometry device (Ultima CPX 790705-205). Maximal Expiratory Flow Volume curves were obtained. Three acceptable and at least two reproducible curves (the two highest FEV1 being within $200 \mathrm{~mL}$ of each other) were obtained in each subject. The highest value of FEV1 was selected for analysis. ESR was determined by the Westergren method (using glass-ware, and performed by experienced personnel), serum total protein concentrations were assessed by routine procedures.

\section{Results and discussions}

A one way between subjects ANOVA was conducted to compare forced respiratory volume in the first second (FEV1) in patients with high anxiety level with patients with a low anxiety level.

The results of the statistical analysis showed a significant difference regarding forced respiratory volume in the first second (FEV1) in the high anxiety scores group ( $M=41.47)$ compared to low anxiety scores group $(M=46.01)$; $F$ (1.149) $=4.212, p=0.042$ (fig.1).

Furthermore, another one way between subjects ANOVA was conducted to compare total serum proteins level in patients with high anxiety with patients with low anxiety.

The results of the statistical analysis showed a significant difference regarding total serum proteins level in the high anxiety scores group $(M=9.2)$ compared to low anxiety scores group $(M=8.6) ; F(1,149)=10.142, p=0.002$ (fig.2).

For the last dependent variable of our experimental design, another one way between subjects ANOVA was conducted to compare erythrocyte sedimentation rate 


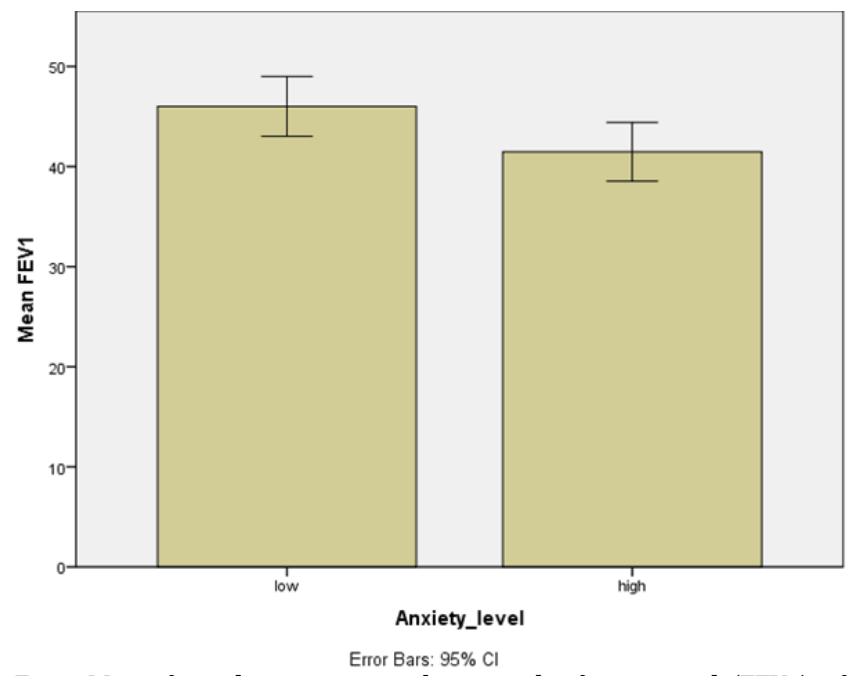

Fig.1. Mean forced respiratory volume in the first second (FEV1) of patients with a low anxiety level compared to patients with a high anxiety level

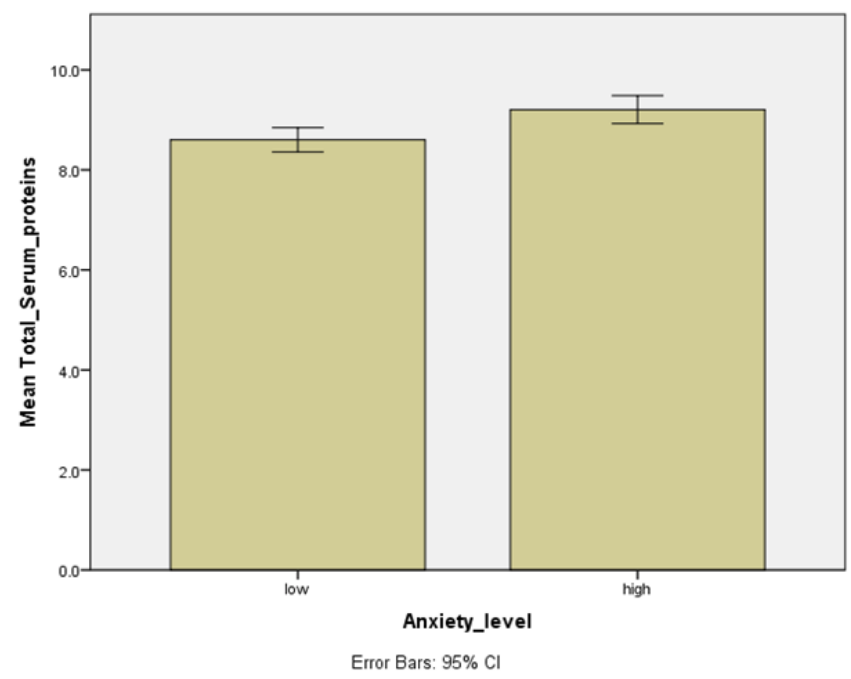

Fig.2. Mean of total serum proteins in patients with a low anxiety level compared to patients with a high anxiety level

(ESR) in patients with high anxiety with patients with low anxiety.

The results of the statistical analysis showed a significant difference regarding erythrocyte sedimentation rate (ESR) in the high anxiety scores group $(M=27.54)$ compared to low anxiety scores group $(M=22.8) ; F(1.149)=4.073, p$ $=0.045$ (fig.3).

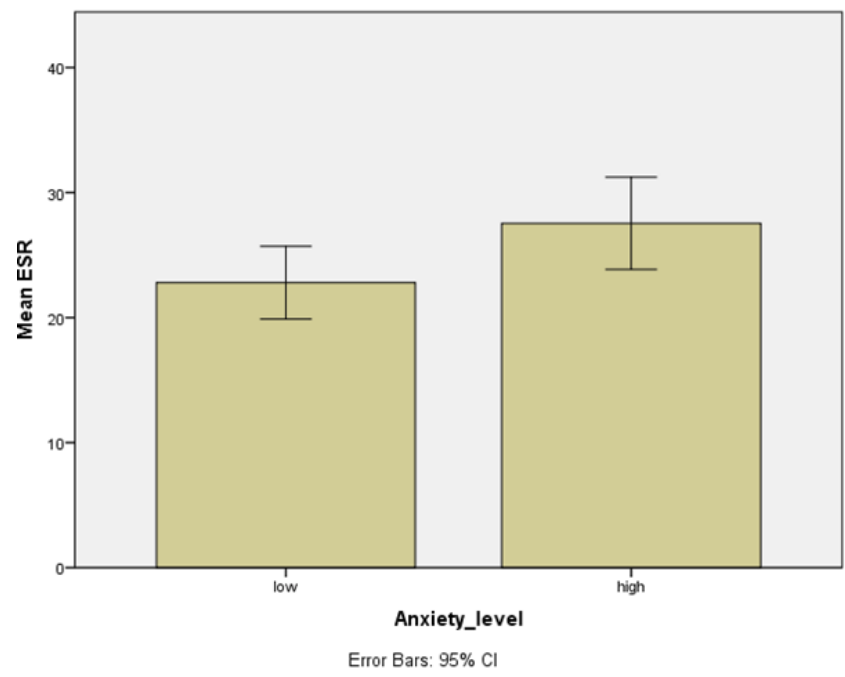

Fig.3. Mean of erythrocyte sedimentation rate (ESR) in patients with a low anxiety level compared to patients with a high anxiety level.
The main purpose of our study was to discover if the biochemical markers generally used for diagnosing COPD (FEV1, total serum protein and ESR) could also predict the level of anxiety of our sample of patients. We formulated three hypotheses at the beginning of our study, each for every biochemical marker of COPD, and how these predictors of COPD could also influence the level of anxiety in our patients who suffer from COPD. The results of our statistical analysis showed significant results for all of our assumptions. For the first hypothesis, the statistical analysis showed that there were significant differences between the high anxiety group and the low anxiety group regarding the level of FEV1 $(p=0.042)$. More specific, the group of patients with a higher level of anxiety had a lower level of FEV1 compared with the patients with a low level of anxiety ( $M=41.47$ compared to $M=46.01)$. The second hypothesis was also confirmed by our statistical analysis. There were significant differences between the two groups (high anxiety vs. low anxiety) regarding the total serum proteins level $(p=0.002)$. The patients with a high level of anxiety had a higher level of total serum protein $(M=9.2)$ compared to patients who presented a low level of anxiety $(M=9.2)$. Finally, for our third hypothesis, the statistical analysis also presented significant results. There were statistically significant differences between the high-low anxiety groups regarding the ESR level $(p=0.045)$. More specific, patients in the high anxiety group had a higher level of ESR $(M=27.54)$ compared to the low anxiety group ( $M=22.8$ ). Therefore, based on our results we can state that patients with more severe COPD (measured by the FEV1) also present a higher level of anxiety. Furthermore, we can assert that the biochemical markers of inflammation (total serum proteins and ESR) could not only predict how severe was the COPD but also the level of anxiety showed by the patients from our study.

The link between the severity of COPD and the level of anxiety has been broadly studied and demonstrated [33]. In addition, for the last twenty years, the lifetime prevalence of anxiety or anxiety disorders in patients with various respiratory disorders has been explored in many studies. The results of these studies show that lifetime prevalence for anxiety disorders in patients with COPD ranges from 10 to $96 \%[35,36]$. Furthermore, it has also been demonstrated that anxiety and panic disorders occur more frequently in patients with COPD compared to the general population $[37,38]$. Therefore, it is of great importance to study anxiety prevalence in this population. Nevertheless, few studies have investigated the relationships between the level of anxiety in COPD patients and the variables that may explain why this population of patients presents such high levels of anxiety. Finding the variables or the molecular mechanism behind this connection might help in developing clinical or therapeutic interventions. The few studies that examined the possible variables that lay behind the high level of anxiety observed in COPD patients showed that greater levels of anxiety were able to find only two variables. A high level of anxiety was associated with poor satisfaction with marital relationships and smokers/nonsmokers status $[8,39]$.

In addition, sleep quality is another factor that should be taken into the consideration. Having difficulty in falling asleep was found to be a risk factor for anxiety in COPD patients [40]. Furthermore, it is well known that sleep disorders are integral parts of anxiety disorders. Additionally, anxiety is also associated with dyspnea, fatigue and poor quality of sleep, which are al known symptoms of COPD [40]. With these in mind, a connection between sleep disorders and anxiety in COPD patients seems more than plausible. 
Thus, sleep disturbances are common in patients who suffer from COPD and these patients are more at risk to have a poor sleep quality. Furthermore, individuals with COPD are likely to experience anxiety, depression, sleep disturbance, and problems with daily functioning [41-43]. However, further studies are necessary to discover if sleep disturbance may explain the high anxiety levels observed in COPD patients.

The present paper shows that ESR and total serum proteins are not only indexes of inflammation in stable COPD patients, butalso predictors of anxiety levels in these population. Furthermore, both total serum protein and ESR are inversely related to FEV1. However, there are authors who suggest that ESR may not be related to bronchial obstruction. The same authors theorize that total serum proteins have a greater sensitivity in detecting chronic lung inflammation [43]. Unfortunately, while the link between total serum proteins and COPD severity is well proved [4447], the data necessary to prove the connection ESR and COPD severity is lacking.

On the other hand, ESR is reliable biochemical marker of chronic rheumatic conditions. These disorders are characterized by increased serum levels of acute phase reactants [48], so named because they typically increase in acute infections. Therefore, ESR might be more useful as a biochemical marker of COPD complications rather than as a marker of disease severity. However, there is available evidence that is against this hypothesis and that ESR in a good tool in diagnosing COPD. Studies show that total serum proteins increases earlier than ESR in response to respiratory infections, either pneumonia or exacerbated COPD, and declines faster in response to antibiotic therapy. Therefore, from this point of view the level of total serum proteins may be more sensitive than ESR in diagnosing COPD severity [49]. However, studies that investigated the ESR-total serum proteins connection with COPD severity showed that lack of decline of ESR in spite of decreasing total serum proteins frequently marks a condition at high risk of re-infection and worsening health status [50]. Thus, ESR and total serum proteins should not be regarded as singular diagnosing tools but rather complementary biochemical markers of inflammation in COPD. In addition, ESR and total serum protein may also be used to predict the level of anxiety in these patients.

Even more, some related testosterone mechanism can be implicated as our group previously described [49], considering also the relation of this hormone with the superior cognitive functions [52].

\section{Conclusions}

In our sample of patients ESR and total serum proteins could predict the level of anxiety (high or low). This is of greatimportance because the high rates anxiety symptoms found in this atrisk population raise the issue that clinicians should consider screening COPD patients for anxiety. Early diagnosing and treating anxiety symptoms may make a difference in an important dimension that could improve outcomes in this growing group of at risk patients.

\section{References}

1.TIEP, B., Chest, 112, No. 6, 1997, p. 1630.

2.BRENES, G.A., Psychosom. Med., 65, No. 6, 2003, p. 963.

3.ARNE, M., JANSON, C., JANSON, S., BOMAN, G., LINDQVIST, U., BERNE, C., Scand. J. Prim. Health. Care, 27, No. 3, 2009, p. 141. 4.GUDMUNDSSON, G., GISLASON, T., JANSON, C., LINDBERG, E., HALLIN, R., ULRIK, C.S., Eur. Respir. J., 26, No. 3, 2005, p. 414. 5.LACASSE, Y., ROUSSEAU, L., MALTAIS, F., J. Cardiopulm. Rehabil., 21, No. 2, 2001, p. 80.
6.VAN MANEN, J.G., BINDELS, P.J., DEKKER, F.W., IJZERMANS, C.J ., VAN DER ZEE, J.S., SCHADE, E., Thorax, 57, No. 5, 2002, p. 412.

7.KUNIK, M.E., ROUNDY, K., VEAZEY, C., SOUCHEK, J., RICHARDSON, P., WRAY, N.P., Chest, 127, No. 4, 2005, p. 1205.

8.GUDMUNDSSON, G., GISLASON, T., JANSON, C., LINDBERG, E., Respir. Med., 100, No. 1, 2006, p. 87.

9.SZEKANECZ, Z., KOCH, A.E., Arthritis Research \& Therapy, 10, No. 5, 2008, p. 224.

10.WILSON, P.W., Am. J. Med., 121, 2008, p. 15. 11. TUDORAN, M., TUDORAN, C., Nigerian J ournal of Clinical Practice, Nov. 2016; 19, 6: 831-833; WJ CP, DOI:10.4103/1119-3077.180065

12. TUDORAN, M., TUDORAN, C., CIOCARLIE, T., POP, G.N., VELIMIROVICI, D.E., BERCEANU-VADUVA, D.M., Mat. Plast., 56, no. 1, 2019, p. 37-40

13.TKACOVA, R., KLUCHOVA, Z., JOPPA, P., PETRASOVA, D., MOLCANYIOVA, A., Respir. Med., 101, 2007, p. 1670.

14.ARONSON, D., ROTERMAN, I., YIGLA, M., KERNER, A., AVIZOHAR, O., SELLA, R., BARTHA, P., LEVY, Y., MARKIEWICZ, W., Am. J. Respir. Crit. Care Med., 174, 2006, p. 626.

15.SIN, D.D., MAN, S.F., Circulation, 107, 2003, p. 1514.

16.DAHL, M., VESTBO, J., LANGE, P., BOJ ESEN, S.E., TYBJAERG-HANSEN, A., NORDESTGAARD, B.G., Am. J. Respir. Crit. Care Med., 175, 2007, p. 250 .

17.VALIPOUR, A., SCHREDER, M., WOLZT, M., SALIBA, S., KAPIOTIS, S., EICKHOFF, P., BURGHUBER, O.C., Clin. Sci. (Lond.), 115, 2008, p. 225.

18.MACOVEI, L.A., BIRSAN, M., TEODOR, V.I., CRISTOFOR, A.C., IOANID, N., REZUS, E., Rev. Chim. (Bucharest), 68, no. 4, 2017, p. 788. 19.KIMBERLY, M.M., VESPER, H.W., CAUDILL, S.P., COOPER, G.R., RIFAI, N., DATI, F., MYERS, G.L., Clin. Chem., 49, 2003, p. 611.

20.KIMBERLY, M.M., CAUDILL, S.P., VESPER, H.W., MONSELL, E.A., MILLER, W.G., REJ, R., RIFAI, N., DATI, F., MYERS, G.L., Clin. Chem., 55, 2009, p. 342.

21.ZLONIS, M., Clin. Lab. Med., 13, 1993, p. 787.

22.WARD, M.M., J. Rheumatol., 21, 1994, p. 17.

23.REINHART, W.H., Ther. Umsch., 63, 2006, p. 108.

24.EICKHOFF, P., VALIPOUR, A., KISS, D., SCHREDER, M., CEKICI, L., GEYER, K., KOHANSAL, R., BURGHUBER, O.C., Am. J. Respir. Crit. Care Med., 178, 2008, p. 1211.

25.BUIST, A.S., VOLLMER, W.M., MCBURNIE, M.A., Int. J. Tuberc. Lung Dis., 12, 2008, p. 703.

26.KO, F.W., HUI, D.S., LAI, C.K., Int. J. Tuberc. Lung Dis., 12, 2008, p. 713.

27.BOOTIGER, L.E., Acta. Med. Scand., 193, 1973, p. 53.

28.LASCARI, A.D., Pediatr. Clin. North. Am., 19, 1972, p. 1113.

29.RUHENSTROTH-BAUER, G., Klin. Wochenschr., 44, 1966, p. 533.

30.STRAUSS, E.H., Zeitschrift fur Psychologie, 183, No. 1, 1975, p. 119.

31.SCHNEIDER, R.A., Proc. A. Res. Nerv. Ment. Dis., 29, 1950, p. 818. 32.AGHEORGHIESEI CORODEANU, D.T., POROCH, V., 6th LUMEN International Conference on Rethinking Social Action Core Values, 16-19 April 2015, Iasi, Romania, Rethinking Social Action. Core Values, p. 33.

33.ROGOZEA, L., REPANOVICI, A., CRISTEA, L., BARITZ, M., MICLAUS, R., PASCU, A., Proceedings of the 4th WSEAS/IASME International Conference on Educational Technologies (Edute'08), Book Series: Recent Advances in Computer Engineering, Corfu, Greece, 2008, Oct. 26-28, p. 87.

34.POROCH, V., AGHEORGHIESEI, D.T., Postmodern Openings, 9, no. 2, 2018, p. 225.

35.AGHNWA, H.S., ERHABOR, G.E., J. Psychosom. Res., 50, No. 4, 2001, p. 179.

36.GUELL, R., RESQUETI, V., SANGEMIS, M., MORANTE, F., MARTORELL, B., CASAN, P., Chest, 129, No. 4, 2006, p. 899.

37.BRENES, G.A., Psychosom. Med., 65, No. 6, 2003, p. 963.

38.YELOWLEES, P.M., ALPERS, J.H., BOWDEN, J.J ., BRYANT, G.D., RUFFIN, R.E., Med. J. Aust., 146, No. 6, 1987, p. 305.

39.ASHMORE, J.A., EMERY, C.F., HAUCK, E.R., MACINTYRE, N.R., Heart. Lung., 34, No. 4, 2005, p. 270. 
40.HILL, K., GEIST, R., GOLDSTEIN, R.S., LACASSE, Y., Eur. Respir. J., 31, No. 3, 2008, p. 667.

41.COLLOP, N., Respiration, 80, No. 1, 2010, p. 78.

42.AGUSTI, A., HEDNER, J., MARIN, J.M., BARBE, F., CAZZOLA, M., RENNARD, S., Eur. Respir. Rev., 20, No. 121, p. 183.

43.BROEKHUIZEN, R., WOUTERS, E.F., CREUTZBERG, E.C., SCHOLS, A.M., Thorax, 61, 2006, p. 17.

44.DE TORRES, J.P., CORDOBA-LANUS, E., LOPEZ-AGUILAR, C., MUSOR DE FUENTES, M., MONTEJ O de GARCINI, A., AGUIRRE-JAIME, A., CELLI, B.R., CASANOVA, C., Eur. Respir. J., 27, 2006, p. 902.

45.MAN, S.F., CONNETT, J.E., ANTHONISEN, N.R., WISE, R.A., TASHKIN, D.P., SIN, D.D., Thorax, 61, 2006, p. 849.

46. DAHL, M., VESTBO, J., LANGE, P., BOJENSEN, S.E., TYBJ AERGHANSEN, A., NORDESTGAARD, B.G., Am. J. Respir. Crit. Care Med., 175, 2007, p. 250.
47.MELBYE, H., HALVORSEN, D.S., HARTZ, I., MEDBO, A., BROX, J., EGGEN, A.E., NJ OLSTAD, I., Respir. Med., 101, 2007, p. 2541.

48.COLGLAZIER, C.L., SUTEJ, P.G., South. Med. J., 98, 2005, p. 185. 49.BUESS, T., LUDWIG, C., Schweiz. Med. Wochenschr., 125, 1995, p. 120.

50.OSEI-BIMPONG, A., MEEK, J.H., LEWIS, S.M., Hematology, 12, 2007, p. 353.

51.COJ OCARU, C., TURCANU, A., MIHAESCU, T., CIOBICA, A., TIMOFTE, D., ALEXINSCHI, O., ANTON, E., COJ OCARU, E., Archives of Bio. Sci., 67, 2015, p. 257.

52.GURZU, C., ARTENIE, V., HRITCU, L., Cent. Eur. J. Biol., 3, 2008, p. 39.

$\overline{\text { Manuscript received; } 15.12 .2018}$ 